IBAD Sosyal Bilimler Dergisi

IBAD Journal of Social Sciences

dergipark.org.tr/ibad

IBAD, 2022; (12): 397-408

DOI: $10.21733 /$ ibad.1036649

Özgün Araştırma / Original Article

\title{
Doğaya Yönelik Olarak Gelişen Arazi Sanatının Sanatçılar Üzerindeki Etkisi
}

\section{Influence of Land Art Improved Pursuant Nature of Artists}

\author{
Gonca Hülya Yayan ${ }^{1}$ \\ Dajana Sevil Hacısüleymanoğlu2 ${ }^{*}$
}

\section{* Sorumlu yazar}

${ }^{1}$ Doç. Dr., Gazi Üniversitesi, Türkiye

Assoc. Prof. Dr., Gazi University, Turkey

gyayan@gazi.edu.tr

ORCID ID https://orcid.org/0000-0002-2915-3137

${ }^{2}$ Dr. Öğrencisi, Gazi Üniversitesi, Türkiye,

Phd Student, Gazi University, Turkey,

dajanasevil@gmail.com

ORCID ID https://orcid.org/0000-0001-5280-9029

Makale geliş tarihi / First received : 15.12.2021

Makale kabul tarihi / Accepted : : 28.01.2022

\section{Bilgilendirme / Acknowledgement:}

Yazarlar aşağı daki billgillen dirmeleri yapmaktadırlar:

1- Yazarların katkı oranı eşittir.

2- Makalenin yazarları arasında çıkar çatışması bulunmamaktadır.

3- Makalemizde etik kurulu izni ve/veya yasal/özel izin alınmasını gerektiren bir durum yoktur. Nitel araştırma yöntemleri kullanılarak yapılan araştırma makalesi olduğundan etik kurul vb. izinlere gerek duyulmamıştır.

4- Bu makalede araştırma ve yayın etiğine uyulmuştur.

This article was checked by Turnitin. Similarity Index \%02

\section{Atıf bilgisi / Citation:}

Yayan, G. H. \& Hacısüleymanoğlu, D. S. (2022). Doğaya yönelik olarak gelişen arazi sanatının sanatçllar üzerindeki etkisi. IBAD Sosyal Bilimler Dergisi, (12), 397-408. 


\section{ABSTRACT}

Geçmişte doğa ile barışık yaşamayı öğrenen insanoğlu, günümüzde şehirleşmeyle birlikte doğadan uzaklaşmışıır. Bugün yaşadığımız dünyada, nüfusun hızlı artışı yanında sanayileşme ve modernleşme de doğanın kutsal sayıldığı ve korunduğu bu sürece büyük zararlar vermektedir. Bunun sonucu olarak yaşanılan bu olumsuz gelişmeler, insanoğlunun doğaya olan bakış açısını da değişime uğratmıştır. Doğa aslında ilkel toplumlardan bugüne kadar sanatın daima temel kaynağını teşkil etmiştir. Sanatçılarda toplumlardaki gelişim süreçlerine bağlı olarak doğaya olan bakışlarına farklılıklar kazandırmışlardır. Modern çağ öncesindeki dönemlerde doğanın güzelliği ile ilgilenen pek çok sanatçı, günümüzde ise doğanın sömürülmesine dikkat çekmeye çalışmaktadırlar. Bu sanatçılar, eserleriyle yaşadıkları toplumlarda bir bilinç kazandırma rolünü de üstlenmişlerdir. Dolayısıyla teknolojik gelişmelerin sebep olduğu pek çok organik yıkımın hızlandığı günümüzde doğanın önemine vurgu yapan sanatsal hareketlerde de artışlar söz konusu olmaktadır. Bu çalışmada doğanın sanat ile olan ilişkisi ve sanaţ̧ıların doğa duyarllı̆ğı için ürettikleri eserler incelenirken nitel araştırma yöntemlerinden olan eser analizi ve literatür taraması yöntemleri kullanılmıştır. Amaç ise sanatçıların doğayı konu aldığı çalışmalar ele alınarak, kaybedilen değer ve bilincin hatırlatılması olmuştur.

\section{Anahtar kelimeler}

Doğa, Sanat, Sanatçı, Modernleşme, Arazi Sanatı
Mankind, who learned to live in peace with nature in the past, has moved away from nature along with the urbanization today. In the world we live at present, industrialization and modernization, as well as the rapid increase in population, cause great harm to this process in which nature is considered sacred and protected. As a result of this, these negative developments have also changed the perspective of human beings towards nature. In fact, nature has always been the main source of art from primitive societies until today. Depending on the development processes in societies, artists have brought differences in their view of nature. Many artists, who were interested in the beauty of nature in the pre-modern era, are trying to draw attention to the exploitation of nature today. These artists have also undertaken the role of raising awareness in the societies they live in with their artworks. Therefore, there is an increase in artistic movements emphasizing the importance of nature today, where many organic destructions caused by technological developments are accelerating. In this study, while examining the relationship between nature and art and the artworks produced by artists for nature sensitivity, it has been tried to benefit from the methods of work analysis and literature review, which are qualitative research methods. The purpose was to remind the lost value and consciousness by considering the artworks of the artists on nature.

\section{Keywords}

Nature, Art, Artist, Modernization, Land Art 


\section{GíRIŞ}

Geçmişte doğa ile bütünleşerek yaşamını sürdüren insanların, gelişen ve ilerleyen dünya düzeni ile doğadan uzaklaşmış oldukları bir gerçektir. Günümüzde doğanın kutsal sayıldığı, korunduğu bu süreç, geride kalmış ve nüfusun hızlı artışı, sanayileşmenin gelişimi ise doğanın yıpranmasına sebep olmuştur. Maalesef yaşanılan bu gelişmeler doğanın evrensel değerini de arka plana atmıştır. Freud (2011, s. 16) insan uygarlığını; "İnsanların doğanın güçlerine egemen olabilmek için ve onun ürünlerine insanların gereksinimlerini doyurabilmek amaciyla el koyabilmek, öte yandan gereken bütün düzenekleri insanların birbirleriyle olan ilişkileri ve özellikle de ulaşılabilen ürünlerin paylaşımı için düzenleyebilmek üzere kazanmış oldukları bütün bilgi ve beceriler" olarak tanımlamıştır. Günümüzde insan giderek doğadan bağımsızlaşırken kendini doğadan bağımsız bir özne olarak görmeye de başlamıştır (Erzen, 2016, s. 44).

Bugün modernleşmeyle beraber değişen doğa, iklim sorunları da ekolojik sistemin bozulmasını gündeme getirmiş ve doğanın tüm özellikleri ile evrensel bütünlügün devamında da bir rolü söz konusu olmuştur. “Doğadaki bu büyünün bozulması ise insanlığın büyüsünün de bozulmasına yol açmıştır" (Bookchin, 1996, s. 197). Günümüzde insan doğanın yerine geçerken, gereksinimleri doğrultusunda da onu zorlayarak günden güne bozulan bütünlüğün sebebi haline gelmiştir. "Günümüzde modernleşme sürecinde kentsel bunalımlar, ağırlıklı olarak kapitalizmin toplumla doğa arasındaki yaratılmış olan bölünmeyi yansıtmaktadır" (Bookchin, 1996, s. 35). Modernleşme döneminde bu denli farklılıkların ortaya çıarmasının asıl sebebi, sosyal, ekonomik ve toplumsal olarak ilerlemeyle ilgilidir. Modern çağ dediğimiz şey tam anlamıla yeniliklerin zamanıdır. 1945 yılından günümüze kadar uzayan modernleşme çağının hızlı gelişimi, sonraki yıllarda ekolojik bir bilinç oluşumuna da sebep olmuştur. "1960'lı yıllarda ortaya çıkan ekolojik bilinç sadece -doğaya dönme- isteğiyle kalmamış, -ilerleme- terimine karşı çıkmaya da sebep olmuştur. Gitgide sanayileşen, bürokratikleşen, teknikleşen kent ortamında gelişen (yol, su, elektrik, trafik) insanları, doğa özlemine yeşilliğe doğru yöneltmeye başlamıştır" (Tuncer, 1998, s. 53,54). Teknolojinin hızla gelişmesi ve kentleşme ile oluşan bu doğa özlemi sanatçıları ve sanatsal üretimlerini de etkisi altına almıştır.

“Doğa, yani insanın sürekli değişmekte olan çevresi” (Freud, 2011, s. 77), tarihsel süreç boyunca sanatsal üretimlere kaynak oluşturmuştur. Modern çağ öncesi sanat, sanatçılarla doğayı tüm güzellikleriyle bize sunarken yaşadığımız modern çağda ise sanatçllar, eserleriyle doğanın sömürülmesi ve bireyin doğadan kopuşunu çeşitli göndermeler yaparak bilinçlendirme görevini üstlenmişlerdir. Kentleşme ile doğanın ve sanatçıların uğradığı değişim, insanın doğa algısını farklılaştırarak, sanatçının doğaya bakış açısını da değiştirmiştir. Modern sanatçılar için estetik, güzel olandan çok gerçeği yansıtan olmuştur. Fischer (1990, s. 37) için “Sanatçının görevi birlikte yaşadığı insanlara olayların gerçek anlamını açıklamak, toplumsal ve tarihsel gelişmenin gerekliliğini ve kurallarını anlatmak, insanla doğa ve insanla toplum arasındaki temel ilişkiler ve sorunları çözümlemek olmuştur". Günümüzde modern sanatın doğa bilimleri ile ilerlemesi ve izleyiciye sunma şekilleri de geçmişte olduğundan farklı bir hal almıştır. 1960'ların sonunda, doğal malzemeler kullanılarak açık alanlarda gerçekleştirilen çalışmalar, "Yer Sanatı”, "Yeryüzü Sanatı" ya da "Arazi Sanatı" olarak adlandırılmıştır. Bu anlamlar altında yapılan sanatsal hareketler sanatçının doğa algısındaki değişimine örnek olmuştur. "1970'lere gelindiğinde yapılan bu çalışmaların odak noktası sadece doğa ve insanlar arasındaki dengesizlikleri işaret etmek iken sonraları daha anlamlı bir şekilde restorasyon üzerine olmuştur. Bu odaklanma 
doğanın iyileştirilmesi müdahalelerini de beraberinde getirmiş, sanatçılar çalışmalarıyla çevrede olumlu değişiklikler yapmayı hedeflemişlerdir" (Aydın ve Zümrüt, 2013, s. 58). Başlarda Arazi Sanatının çevresel olaylara fazla odaklanmayan daha çok anıtsal ölçeklere sahip bir akım olduğu düşünülmüştür (Strewlow ve Prigann, 2004). Ancak zamanla Arazi Sanatı çevresel sorunlarla ilgilenen ve bu sorunlara karşı duyarlılık sağlamak amaçlı yapılan sanatsal hareketlere dönüşmüştür. Arazi sanatı, sanatçlların doğaya yönelik duyarlılığının bir göstergesi olduğu kadar, sanatın işlevine yönelik bir bilinçlendirme olarak da nitelendirilmiştir (Antmen, 2009, s. 256). Arazi Sanatını diğer akımlardan ayıran özellik ise manzarayı mekana dönüştürerek mekana özgü oluşturulması olmuştur. Doğaya dair bir bilinç oluşumunu amaçlayan ve teknolojiye karşı doğayı kutsal sayan bu yaklaşımı konu alan birçok sanatçıda yer almıştır. Bu sanatsal hareketlerle doğaya olan duyarlılığa vurgu yapmak isteyen sanatçlar, eserleriyle doğaya iyileştirici müdahalelerde bulunmuşlardır. 1960'larda gelişen bu sanatsal hareketin günümüzde de etkisini sürdürdüğü görülmüştür. Bu sebeple yakın geçmiş ve günümüz sanatçıları çalışmaya konu olmuştur. Böylelikle sanatçıların doğayı konu aldığı çalışmalar ele alınarak, kaybedilen değer ve bilincin hatırlatılması amaçlanmıştır. Çalışmada nitel araştırma yöntemlerinden olan eser analizi ve literatür taraması yöntemleri kullanılmıştır.

\section{DOĞAYA YÖNELIKK GELİŞEN DUYARLILIKTA SANATÇININ ETKİṠ}

Sanatsal alanda yapılan hareketler doğanın öneminin vurgulanması bağlamında önemli bir yere sahiptir. "Zaman geçerken ve yirminci yüzyılın kalan son yılları da pekâlâ insanlıkla doğa arasındaki dengelerin yeniden kurulması için son fırsat olabilir" (Bookchin, 1996, s. 41). Bugün doğayı sömürgesi haline getiren insanoğlu, aslında sanat yoluyla doğanın önemine dikkat çekerken aynı zamanda bir farkındalık da yaratmaktadır. Günümüzde insan ile doğa arasındaki bu dengeyi sarsan pek çok yıkıcı teknolojik gelişimler olsa da sanat ile kazandırılan bu duyarlılık değişime giden yolun önemli bir parçasını teşkil etmektedir. Yapılmış olan bazı Arazi Sanatı projeleri ile gelişen doğal süreçlerde uzun yıllardır varlığını sürdürmektedir. Bu yaklaşımlarla sanatçılar, bugünden gelecek kuşaklara bırakacaklarımıza da önemli bir vurguyu da yapmaktadırlar. Bu konuda çalışan günümüz sanatçılar arasında Agnieszka Gradzik ve Wiktor Szostalo, Christo and Jeanne-Claude, Olga Ziemska, Sibel Horada ve Chicago' daki bazı anonim sanatçılar yer almaktadır.

Görsel 1. Tree Hugger, Agnieszka Gradzik and Wiktor Szostalo, Poznan, 2008 (Yoo, 2021).

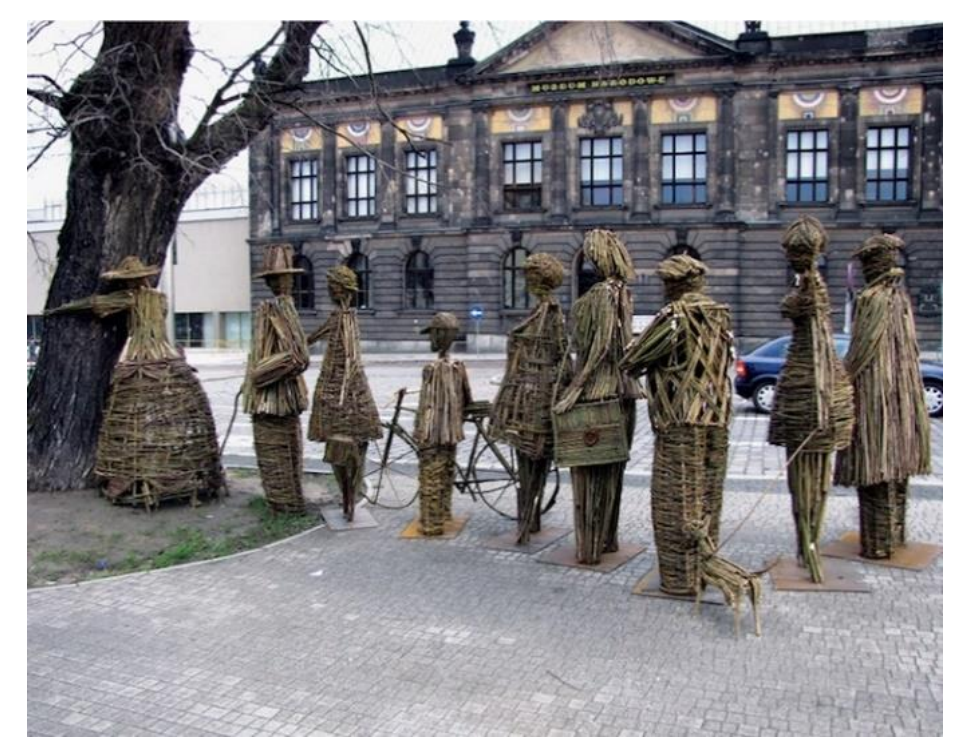


Sanatçıların bu konuda yaptıkları eserlerini sırasıyla inceleyecek olursak, Agnieszka Gradzik ve Wiktor Szostalo' nun ortak eserinde, doğaya verilmesi gereken değeri vurgulamışlardır. “Tree Hugger" adlı eserde, Polonyalı heykeltıraş sanatçıları Agnieszka Gradzik ve Wiktor Szostalo çevresel bir sanat projesini ele almışlardır. Geliştirilen bu projenin amacı, insanın doğa ile olan kişisel ve samimi ilişkisini tekrar keşfetmesini sağlamaktır. Sanatçlar görsel 1'de yer alan çevresel çalışmayı şu sözlerle açılamışlardır:

“Tree Hugger" Projesi, doğayla olan ilişkimizi çok kişisel ve samimi bir düzeyde yeniden keşfetmemize yardımcı olmak için tasarlanmış ve devam eden bir çevre sanatı çalışmasıdır. Dallardan, çubuklardan, asmalardan ve diğer doğal malzemelerden yapılmış bu eğlenceli heykeller, bize insanların hala doğal çevremizin bir parçası olduğunu hatırlatmaktadır. Dışarıda arkadaşlarımızla oynarken ağaçlara tırmanmakta günlük deneyimimiz bir parçasıdır. Hiç ağaca sarılmadan tırmanan oldu mu? Projemiz yerel topluluklara ulaşmak için mükemmel bir fırsat sunmaktadır. Çalışmamız çevre için ayağa kalkmanın eğlenceli ve politik olmayan bir şekilde yapılabileceğini, çağdaş sanatın eğlenceli olabileceğini bizlere göstermektedir. "Tree Hugger" Projesi neredeyse her yerde gerçekleşebilmektedir. Yerel parkınızda, okulunuzda veya topluluk bahçenizde başlı başına bir etkinlik olabilir veya insanların bir araya geldiği hemen hemen herhangi bir yerel topluluk festivaliyle bağlantılı olarak da inşa edilebilmektedir (Layyla over the rooftops of the world, 2013).

İki sanatçının başlattığı bu proje, Polonya'nın Poznan şehri ile sınırlı kalmayarak, birçok ülkede de uygulanmıştır.

Görsel 2. Tree Hugger, Agnieszka Gradzik and Wiktor Szostalo, Brooklyn Ny, 2009 (Gradzik ve Szostalo, 2021).
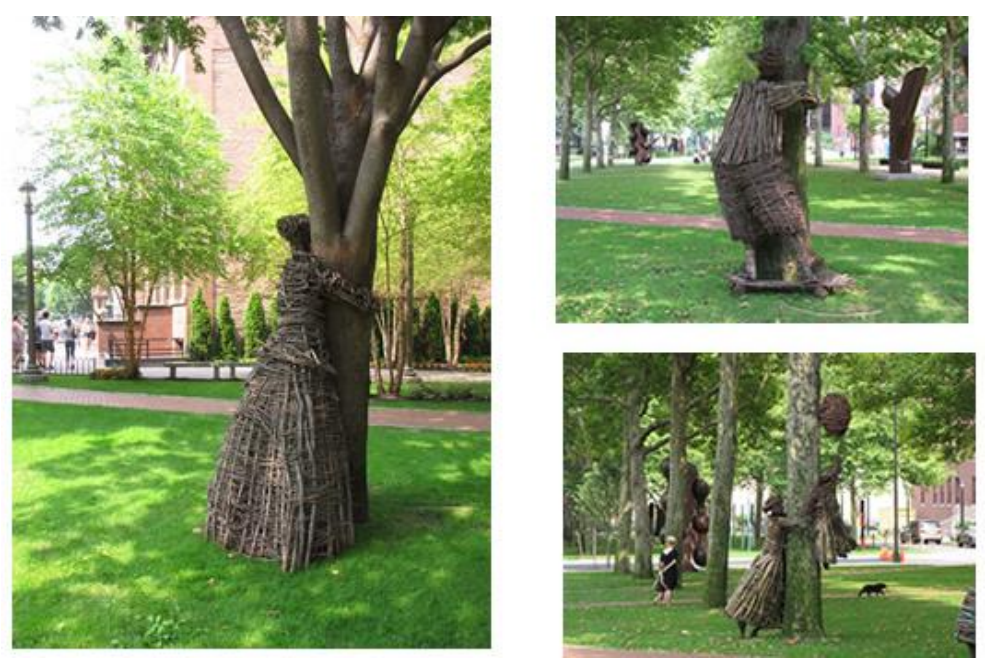

Sanatçların görsel 2'de yer alan çalışmasında, objeler ağaca sarılarak yapılmış olup projenin Brooklyn'de gerçekleştirilmiş bir örneğidir. Sanatçılar, gittikleri her yerde buldukları organik malzemeler ile projenin birçok farklı temsilini gerçekleştirmektedirler. Görsel 1'de ağaca sarılmak için bir dizi insanın sıraya girdiği görülürken görsel 2' de ağaç ile birey arasındaki ilişki daha da samimi bir halde karşımıza çıkmaktadır. 
Görsel 3. Tree Hugger, Agnieszka Gradzik and Wiktor Szostalo, Vienna, 2007 (Gradzik ve Szostalo, 2021).
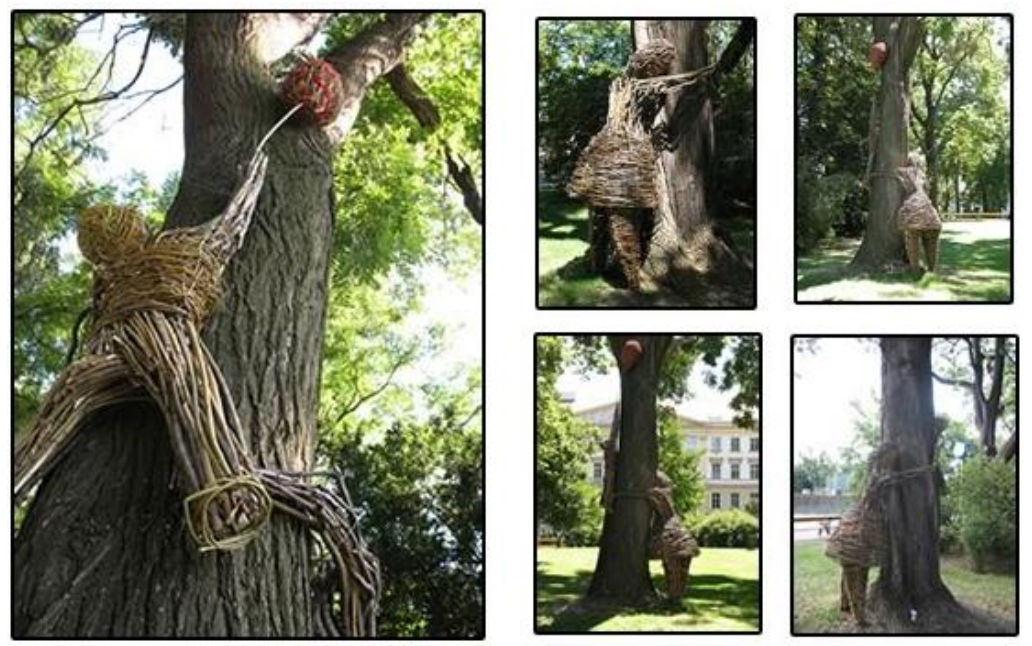

Sanatçıların görsel 3'te yine farklı bir ülkede yapılmış olan bir diğer proje görülmektedir. Bu kez eserde ağaca sarılan ve tırmanan çocuk figürleri dikkat çekmektedir. Projelerde yer alan bireylerin sayısı ya da yaş grubu değişkenlik gösterirken mesaj ve amaç hep aynıdır. Sanatçılar oluşturdukları bu projeler ile doğanın insanla olan ilişkisine vurgu yapmaktadır. Doğaya verilmesi gereken özen ve sevginin aslında ne kadar kolay ve eğlenceli olabileceği gösteren bu eserler, doğa ile içe içe yaşayan insanın geçmişi ile olan birer anıları niteliğinde olmuştur. Projenin uygulanabilirliği, doğanın bize sunduğu sınırsızlığa bir vurgu sayılabilir. Günümüzde doğanın insanlığa sunduğu sayısız imkan ve güzellik karşısında insan, hakimiyet duygusu ile hareket etmektedir. Ancak bizler doğanın değerlerine sahip çıkarak onu geleceğe birakmakta görevli sayılmalıyız. “Doğaya asla tam olarak hâkim olamayız ve insanın kendisi de bu doğanın bir parçası olan organizmamızda her zaman geçici, uyum ve verim kapasitesi de sınırlı bir yapı olarak kalacaktır" (Freud, 2011, s. 50).

Görsel 4. Wrapped Tree, Christo and Jeanne - Claude, İsviçre, 1998 (Soley, 2021).

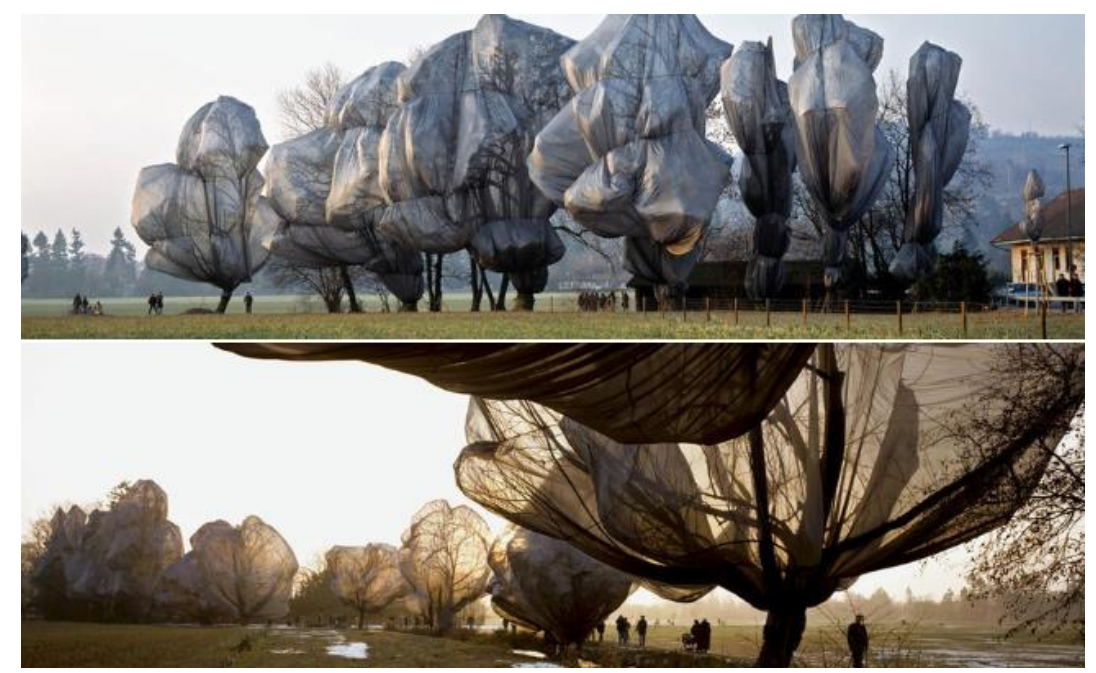

Arazi sanatı projeleri ile tanınan diğer sanatçılardan Bulgaristan doğumlu Christo ve NewYork doğumlu Jeanne Claude, 1998 yılında İsviçre'de görsel 4'te yer alan ağaç giydirme projelerini gerçekleştirmişlerdir. 178 Ağacı polyester kumaşla kaplayarak, ışık ve gölge oyunlarıyla değişik 
formlar kazanmalarını sağlamışlardır. Bu görsel şölenin yanı sıra yaptıkları kaplamalar ile ağaçları bir ay boyunca kötü hava şartlarından da korumuştur. İlerleyen zamanlarda sanatçlar, projeyi genişletmek istemiş ülke görevlilerinden gerekli izinleri alamamışlardır. Doğada gördüğümüz her şey gibi ağaçlarda ekolojik sistemde çok önemli bir yer kaplamaktadır. İklim kontrolünü sağlayan ağaçlar ve bitkiler hava arıtma, karbon birikimini azaltma, toprak ve su dengesini koruma, gürültüyü azaltma, çevresel kirliliğini önleme gibi birçok işlevi yerine getirerek yeryüzünü yaşanabilir bir ortama dönüştürmektedir. Sanatçılar tarafından doğada yapılmış bu tür projeler, izleyiciyi estetiğin yanı sıra zihinsel bir algılama sürecine dahil etmektedir. Böylece izleyici teknoloji karşısında yıkıma uğrayan doğaya dair bir bilinçlenme evresine girerken bu aşamada insanın doğa üzerinde kurduğu tahakkümü de anımsatabilmektedir.

Görsel 5. Christo and Jeanne - Claude, Wrapped Tree, 1998 (Jager, 2021).

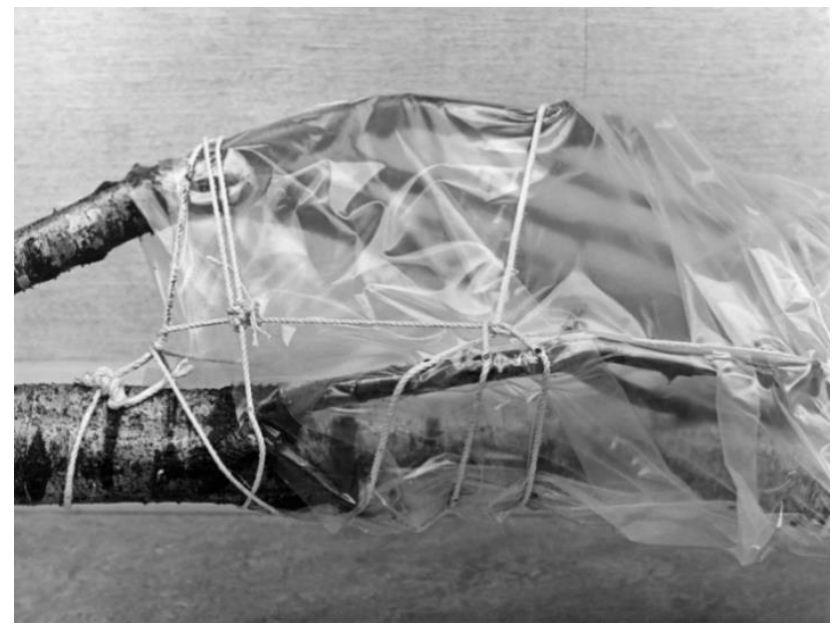

Sanatçı Christo ve Jeanne, canlı ağaçları sarmadan önce kökünden sökülmüş ya da kesilmiş olan ağaçları sararak iç mekanlarda yerleştirmeler yapmışlardır. Görsel 5'te yer alan ağaç, iç mekâna yerleştirilerek izleyiciye sunulmuştur. Görsel $4^{\prime}$ teki paketlenmiş canlı ağaçların estetik görünümünün yanı sıra görsel 5 'teki eserde yere serilmiş bu ağacın görüntüsü cansız bir bedeni anımsatmaktadır. Bu eser kökünden sökülen ve yersizce kesilen sayısız ağaca gönderme niteliği taşıyan bir çalışma olarak değerlendirilebilir.

Günümüzde çevremizde bulunan organik malzemeleri sanatına dahil eden birçok sanatçı bulunmaktadır. Bunlardan bir diğeri de Polonyalı heykeltıraş Olga Ziemska'dır. Sanatçı eserlerinde geri kazandırılmış söğüt dallarını, kil, alçı gibi doğal malzemeleri kullanarak insanlığın doğal dünya ile olan bütünleşmesine yönelik yerleştirmelere yer vermektedir. 
Görsel 6. Stillness in motion: The Matka Series, Olga Ziemska, Romania (Ziemska, 2021).

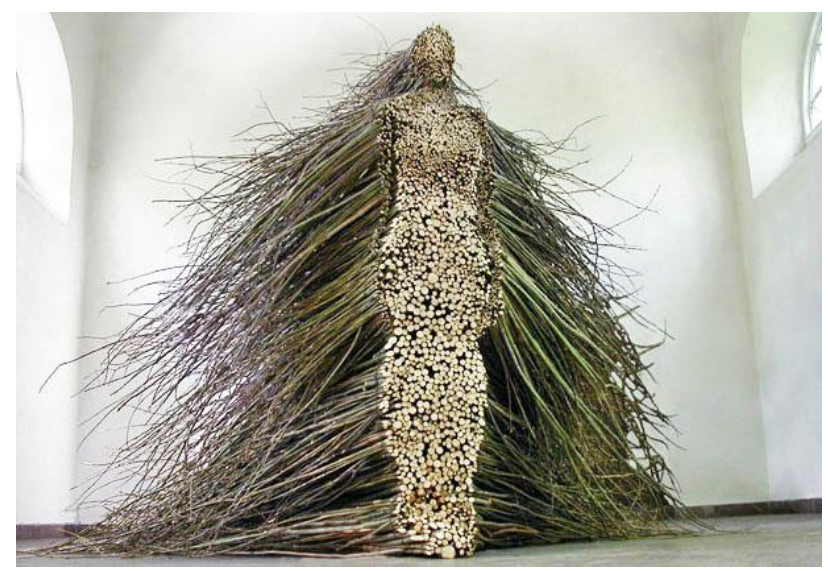

Sanatçı dünyanın birçok yerinde doğal malzemeler ile heykeller oluşturmuş ve gittiği yerlere özgü malzemeleri eserlerinde kullanmıştır. Olga Ziemska eserlerinin yapım aşamasını şöyle açıklamıştır;

Belirli bir ülkenin veya bölgedeki doğal ortam ve malzemelerinin çalışmalarıma nasıl yansıyacağını, doğal çevremizin bizi nasıl etkilediğine sşık tutarken kültürümüzün ve kimliğimizin yaratılmasında bize yardımcı olacağını düşünmekteyim. Çevremdeki dünya, iş yaratmak ve ilham almak için ihtiyaç duyduğum tüm malzemeleri, unsurları ve koşulları sunmakta (Uptas, 2020).

Sanatçı gittiği yerlere uyum sağlayarak, gördüğü ve özümsediği çevreyi bozmak yerine doğanın ona sunduğu malzemelerle eserlerini üretmektedir. Sanatçının görsel 6' da yer alan "The Matka Series" adlı eseri organik malzemeler ile gerçekleştirmiş olan bir çalışmadır. "Matka" kelimesi Lehçe'de "anne" anlamına gelmektedir. Sanatçı bu eseri; "ilk fiziksel çevremiz olan rahmi temsil eder" diyerek tanımlamıştır (Noorata, 2013). Sanatçının organik malzemeler ile ürettiği anne figürü, kişinin dünyaya geldiğindeki ilk ortamı simgelediği gibi kullanılan malzeme yolu ile bu ortamın doğa olduğuna da vurgu yapmaktadır. Sanatçının da ifade ettiği gibi aslında doğa, gördügümüz her şeyin anasıdır (Newall ve Pooke, 2021, s. 34).

Görsel 7. Becoming, Olga Ziemska, Taiwan, 2019 (Ziemska, 2021).

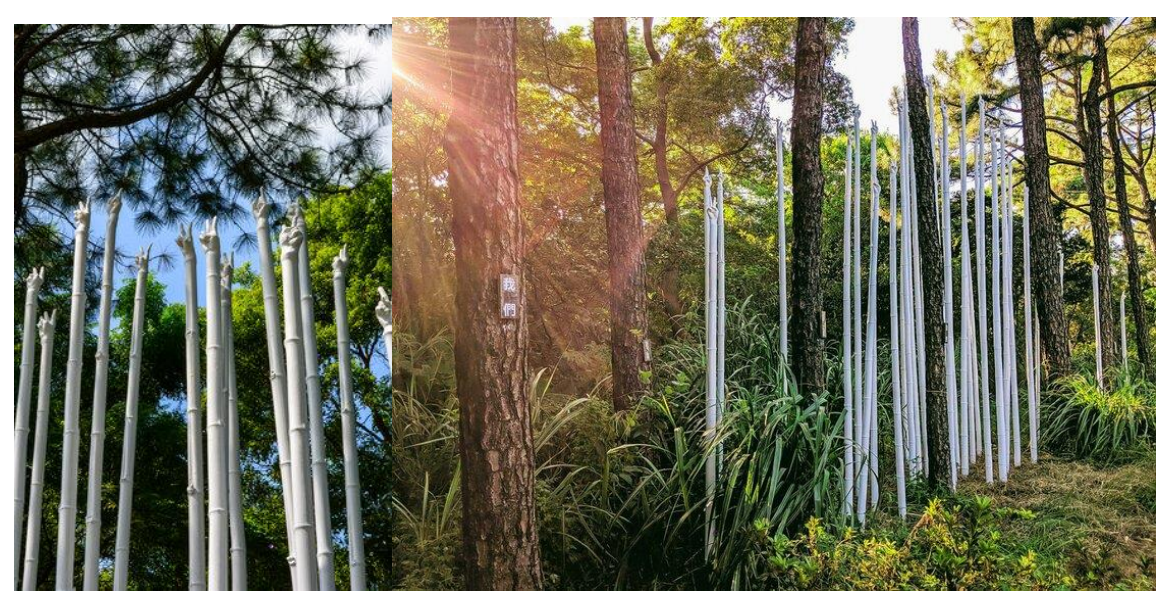

Sanatçının bir diğer çalışması ise, ormanlık bir alanın içine yerleştirilmiş ve boyanmış bambulardan oluşmaktadır. Görsel 7'de yer alan ve ormanın içinde insan eli değmiş küçücük bir ormancık hissi veren bu çalışma, aynı zamanda önemli bir mesajı da içermektedir. 
Bambuların tepesinde, plasterden yapılmış eller dikkat çekmektedir. Ellerin izleyiciye verdiği mesaj ise nettir: "Barış". Ormanın içinde yer alan bu görüntü, insan ile doğa arasındaki barışı sağlamak için yapılmış açık bir çağrı niteliğini taşımaktadır. Beyaz renk kullanımının amacı ise doğanın insan karşısında pes edişinin bir simgesi olarak değerlendirilebilir.

Görsel 8. Chicago, Anonim, 2014 (Sanatatak, 2021)

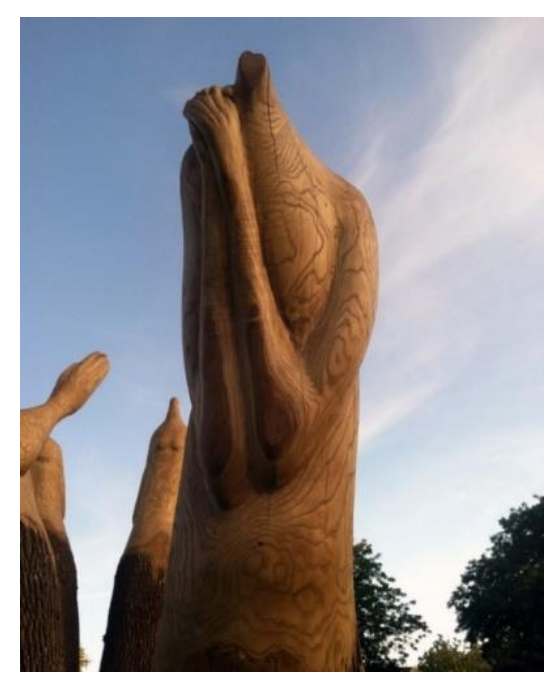

2014 yılından beri Chicago'daki ise kuruyan ve hastalanan ağaçlar bölge sanatçıları tarafından ahşap heykellere çevrilmektedir. Asya kökenli zümrüt yeşili bir böcek 2002' den beri Kuzey Amerika'da dişbudak ağaçlarının ölümüne sebep olmuş ve bu salgın sonucu hastalanan ağaçlarda yerinden sökülmüş veya kesilmiştir. Chicago'da bugün bambaşka bir yöntem uygulanırken, 2014 yılından beri sanatçılar hastalanan bu ağaçları kesmek yerine sanat eserlerine çevirmektedirler. Görsel 8'de, gösterilen eser bu anonim eserlerden biridir. Heykele dönüştürülmüş bu eserde elleri ile af dilermişçesine gökyüzüne uzanan bir insan formu dikkat çekmektedir. Ağacın insan formundaki af diler duruşu, ironik bir yaklaşım olarak değerlendirilebilir.

Görsel 9. Chicago, Anonim, 2014 (Sanatatak, 2021)

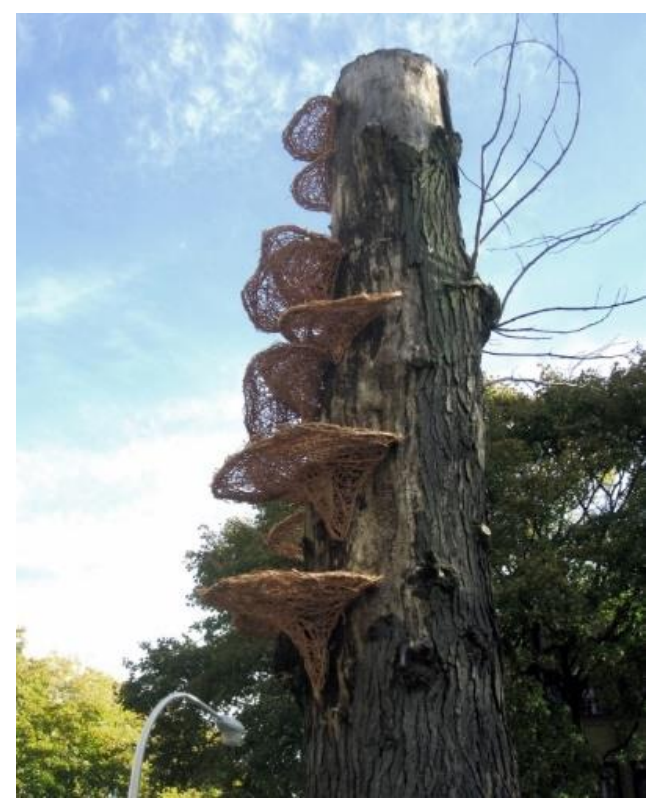


Görsel 9' daki anonim heykelde yine hastalanan bir ağacın sanat eserine dönüşümüne bir örnek niteliğindedir. Üretilen bu eserde de ironik bir yaklaşım söz konusudur. Ağacın üzerine yuvayı andıran basamakları yerleştiren sanatçılar, doğadaki canlılar için yuva olan ya da insanın barınması için yok ettiği ve sömürdüğü ağacın değerine bir şekilde vurgu yapmaktadırlar. Her iki örnek çalışma da aslında ağacın önemini anlatmak istemektedir. Sanatçlar bu çalışmalar ile yok olan doğaya dikkat çekmeye çalışırken şehrin manzaralarına da sayısız sanat eserleri kazandırmışlardır.

Görsel 10. Orman, Sibel Horada, 2017 (Horada, 2021)

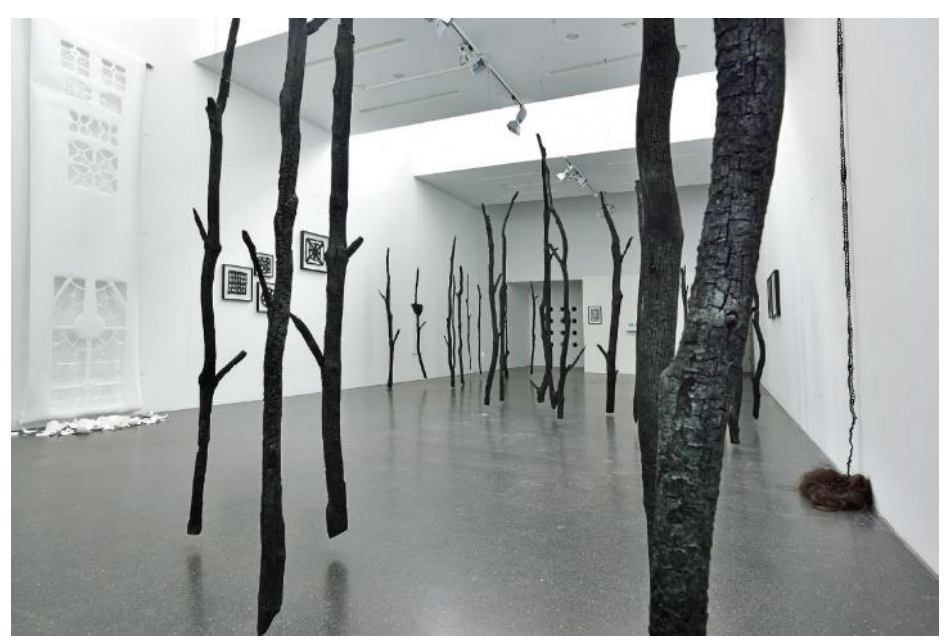

İstanbul doğumlu Sibel Horada, 2017 yılında İstanbul Galerist'te gerçekleştirdiği Dark Deep Darkness and Splendor sergisinde “Orman"'la (2017) Shou Sugi Ban adlı Japonya'da geliştirilen bir tekniğe gönderme yaparak yakılmış kayın ağaçlarından bir ormana kurgu yapmıştır (Soley, 2019). Bu teknik ile odunlar yakılarak etrafında karbondan bir katman oluşturulmuş ve böylece odunların hava şartlarında çürümeye ve ateşe çok daha dayanıklı hale getirilmiştir. Sanatçı görsel 10'da yakılmış bir ormanın görüntüsünü simgelerken bu yerleştirmeyi, yalnızlık, tamir ve toplu direniş ile de ilişkilendirmiştir. Yapılan bu teknikle doğanın insanlık tarafından evcilleştirilme çabası gösterilmeye çalışılırken çeşitli müdahalelerle işlevsel hale getirilmeye çalışılan doğaya ait organik malzemeler, sanatçının bu eseriyle özgür ve vahşi bir havayı yaratmiştır.

\section{SONUÇ}

İnsanoğlu geçmişte doğa ile içe içe yaşarken, onu korumuş ve kutsal saymıştır. Nüfusun artışı, sanayileşme ve modernleşme ile birlikte insanın doğa algısı değişime uğramıştır. Günümüz insanı da artık doğaya tahakküm eden bir duruşu sergilemektedir. Geçmişten bu yana doğayı kaynak olarak kullanan sanatçı, doğanın güzelliğini konu alırken modernleşmeyle birlikte farklı bir algıyı da izleyicisine sunmuştur. Günümüzde doğanın sömürülmesi ve değerinin geri plana atılması, sanatın konusu olan güzelliğinin de önüne geçmiştir. 1960'larda modernleşme ile ortaya çıkan Arazi Sanatı başlarda, sadece estetik olarak doğaya müdahale olarak görülürken sonrasında izleyiciye estetik bir algının yanı sıra kaybedilmeye başlanan doğaya dikkat çekme ve bilinçlendirme çabası içine girmiştir. Bu yaklaşım ile sanatçılarda eserlerinde organik malzemeleri ya da doğanın kendisini mekân olarak kullanarak tüm dikkatleri buraya çekmeyi de başarmışlardır. 
$\mathrm{Bu}$ araştırmadaki sanatçıların doğaya yönelik yaptıkları çalışmalardan yola çıkarak incelendiğinde iki farklı yaklaşım ile doğaya olan duyarlılıklara vurgu yaptıkları görülmektedir. Tüm sanatçılar en önemli vurgulama olarak Arazi Sanatından faydalanmışlar ancak doğrudan ve ironik olmak üzere iki farklı yaklaşımı da sergilemişlerdir. Agnieszka Gradzik ve Wiktor Szostalo, Christo ve Jeanne - Claude ve Sibel Horada'nın çalışmalarında doğa duyarlılığına doğrudan bir vurgu görülmektedir. Sibel Horada ve Christo ve Jeanne- Claude'nin eserlerinde ise doğaya olması gereken korumacılığın yanı sıra, verilen zararlarda söz konusu olmuştur. Agnieszka Gradzik ve Wiktor Szostalonun "Tree Hugger" adlı projesi ise direkt olarak doğaya unutulan sevgiyi konu almakla beraber her yerde uygulanabilecek bir proje halinde sunulmuştur. Sanatçlar projeyi, doğal ortamda bulunan organik malzemeleri kullanarak, izleyiciyi de dahil edebilecekleri kolektif bir yapı haline getirmişlerdir. Çalışmaya konu olan bir diğer sanatçı Olga Ziemska'nın ve Chicago'da ismi bilinmeyen sanatçılar tarafından yapılmış heykel eserlerde ise doğrudan bir mesaj yerine ironik bir yaklaşım söz konusudur. Empatik bir duruş sergileyen bu sanatçılar, doğadan af diler ya da barış isteği yapar gibi oluşturdukları eserlerinde, insanın doğa için sergilemesi gereken duruşu ironik bir biçimde izleyiciye sunmuşlardır. Olga Ziemska gittiği yerlerde bulunan organik malzemeleri kullanırken, Chicago'daki heykel tıraşlarda kesilecek ağaçları heykellere çevirerek doğaya olan saygı ve değeri de vurgulamışlardır.

İnsanoğlu doğa üzerindeki yaptığı çeşitli değişimlerle kendisine ait bir yaşam imkanı sağlarken, aslında geleceğe yönelikte bu önemli mirası tehlike altına sokmaktadır. “...insanoğlu, deyim yerindeyse, bir tür protezli tanrı haline gelmiştir" (Freud, 2011, s. 50). Doğa üzerinde sergilenen bu güç, günümüz teknolojileri ile ciddi boyutlara gelmiş olmasına rağmen, çalışmada yer alan eserlerde görüldüğü üzere çeşitli sanatsal hareketlerle de sanatçıların toplumu bilinçlendirme yönündeki büyük rolleri üstlendiğini göstermektedir. Modernleşme ile başlayan ve günümüze kadar devam eden süreçte sanatçılar, insan ile doğa arasındaki dengeyi sağlama çabasında önemli bir tavır sergilemiştir. Bugün geleceğe bırakılacak en değerli şeyimiz olan doğa, sanatçılarımızın izleyiciye yarattığı farkındalık ile tekrar anlam kazanmaktadır.

\section{KAYNAKÇA}

Antmen, A. (2009). 20. yüzyıl batı sanatında akımlar. Sel Yayıncılık.

Aydın, İ. \& Zümrüt, Y. (2013). Doğa ve sanat ekseninde farklı yaklaşımlar. Sanat ve Tasarım Dergisi, 4(4), 53-78.

Bookchin, M. (1996). Ekolojik bir topluma doğru. A. Yılmaz (Çev.). Ayrıntı Yayınları.

Erzen, J. N. (2016). Çoğul estetik. Metis Yayınları.

Fischer, E. (1990). Sanatın gerekliliği. C. Çapan (Çev.). Verso Yayıncılık A.Ş., İmge Kitapevi Yayınları.

Freud, S. (2011). Uygarlı̆̆ın huzursuzlŭ̆u. H. Barışcan (Çev.). Metis Yayınları.

Kandinsky, W. (2010). Sanatta ruhsallık üzerine. Altıkırkbeş Yayın. 
Layyla over the rooftops of the world. (2013, Ocak 11). https:/layylaovertherooftopsoftheworld.wordpress.com/2013/01/11/the-treehuggerproject/

Newall, D. \& Pooke, G. (2021). Sanat tarihinin elli temel metni. A. E. Pilgir \& E. T. Akı (Çev.). Ayrıntı Yayınları.

Noorata, P. (2013, Nisan 13). My Modern Met. https://mymodernmet.com/olga-ziemskastillness-in-motion-the-matka-series/

Soley, U. (2019, Mart 7). https://t24.com.tr/k24/yazi/ormanlardan-galeri-muze-bienal-ve-dijitalalanlara-guncel-sanatta-agaclar,2190

Strewlow, H. \& Prigann, H. (2004). Ecological aesthetics art in environmental design: Theory and practice. Birkhauser-Publishers for Architecture.

Tuncer, N. D. (1998). Geçmişten günümüze land art sanat akımı ve diğer disiplinler ile ilişkisi. Sanatta yeterlilik tezi, Marmara Üniversitesi, İstanbul.

Uptas, A. (2020, Kasım). Demilked. https://www.demilked.com/stillness-in-motion-olgaziemska/

\section{GÖRSEL KAYNAKÇA}

Gradzik, A. \& Szostalo, W. (2021, Aralık 3). Treehuggerproject. http://www.treehuggerproject.com/events/pratt.html

Gradzik, A. \& Szostalo, W. (2021, Aralık 3). Treehuggerproject. http://www.treehuggerproject.com/events/stadtpark.html

Horada, S. (2021, Ekim 10). Sibel Horada. https://sibelhorada.com/portfolio/forest/

Jager, A. d. (2021, Aralık 3). Christojeaneclaude. https://christojeanneclaude.net/artworks/indoor-installations

Sanatatak. (2021, Ekim 10). Sanatatak. http://www.sanatatak.com/view/hasta-agaclari-kesmekyerine-sanata-donusturuyorlar

Soley, U. (2021, Ekim 10). https://t24.com.tr/k24/yazi/ormanlardan-galeri-muze-bienal-vedijital-alanlara-guncel-sanatta-agaclar,2190

Yoo, A. (2021, Ekim 10). My modern net. https://mymodernmet.com/environmental-artcalendar/

Ziemska, O. (2021, Ekim 10). Olga Ziemska Studio. https://www.olgaziemska.com/environmental-art/project-six-prfmp

Ziemska, O. (2021, Aralık 3). Olga Ziemska Studio. https://www.olgaziemska.com/environmental-art/project-four-bhsjx 